It seems, however, that for the foreseeable future we shall have, as the authors point out, to be content with a classification based mainly on the classical criteria of gross morphology, modified in small ways by experimental data. Such a system may indeed prove to be the most convenient all-purpose one in the long run, even should it become possible to make phylogenetic or physiological classifications for special purposes.

T. G. TuTiN

\section{STUDIES IN BUSINESS ORGANIZATION}

\section{Business Enterprise}

Its Growth and Organization. By Prof. Ronald S. Edwards and Harry Townsend. Pp. xvii +607 . (London : Macmillan and Co., Ltd.; New York : St. Martin's Press, Inc., 1958.) 60s. net.

Tran

HE authors have produced a book on the growth and organization of business that is at once scholarly and immediately intelligible to the layman ; this is no mean achievement. The book is based on a wealth of case material built up over the past twelve years. During that time evening seminars on industrial administration have been held at the London School of Economics, the main feature of each seminar being the discussion of a previously circulated paper written by an industrialist or Civil servant. The incorporation of 'potted' case histories from these papers and elsewhere without making the narrative disjointed has been skilfully done.

The book is divided into four parts dealing respectively with the birth and growth of firms, factors determining the size and specialization of firms, the Government and industry, and the future of industry in Britain. There is a steady and noticeable change of emphasis as one proceeds through the book away from the descriptions, explanations and analyses which dominate Part 1 and towards the exposition of what the authors strongly believe to be good for us, which-necessarily in view of its subjectmatter-dominates Part 4. Thus, when we read in Part 3 that, " . . the reader should be warned that he is dealing with two authors who believe that every extension of central power should be very amply justified before it is granted, and that the onus of proof should always lie with those who propose centralisation", we are merely receiving confirmation of a suspicion that has been building up over several chapters.

Parts 1 and 2 draw especially heavily on the case material referred to above, which provides numerous examples illustrating the developing theme; each of these Parts has several appendixes comprising papers which have been read to the seminar. Part 3 provides an admirable account of the relations between the Government and industry, and includes excellent chapters on Government organization of industrial research, the location of industry, the steel industry and the organization of nationalized industries.

The dust-jacket tells us that the book is addressed to students of industrial economies and government, and to practising business men. It will be surprising if it does not find favour with a much wider reading public than this. In particular, students of science and technology who intend to go into industry should find it a most worth-while addition to their shelves.

$$
\text { L. G. JAEGER }
$$

\section{ARCH/EOLOGY OF SOUTH-EAST ENGLAND}

\section{An Archæology of South-East England}

By Gordon J. Copley. Pp. $324+28$ plates. (London : Phoenix House, Ltd., 1958.) 50s. net.

T $T$ is stated on the dust-cover that the information contained in this volume can otherwise be found only in numerous scattered publications, many of them of a specialist nature, and that it is a book unlikely soon to be superseded. With these statements any reviewer must agree. Dr. Copley has studied widely and, so far as the limits of his space allow, has covered the ground of the wide area with which he is concerned. The author of such a work of compilation must of necessity begin by fixing in his mind the sort of public for whom he will be catering. I imagine Dr. Copley has written primarily for the instructed amateur. But the maps and, above all, the gazetteer will be welcomed by the specialist as well.

The work opens with some general chapters dealing with such problems as the amateur in archæology and the natural background. These are followed by chapters on periods--Palæolithic to Middle Agesand in conclusion there is a study of locality and of place names, a bibliography and a gazetteer. In the period chapters there are distribution mapsnecessarily of very small scale-and later in the volume, grouped together, will be found 28 half-tone illustrations. The early chapters depend, to a large extent, on Zeuner's work. He is a good guide, even though everyone does not agree with all he suggestsespecially his dating. But for the instructed amateur the opening phases of the book will be found useful. The geo-chronology is, of course, far more complicated than could be dealt with in the short account which space allows, but a generalized picture is given. The Neolithic and Early Metal Age chapters, again within the limits of available space, are excellent. Naturally for the later periods, as so much more evidence has survived, the account has to be more sketchy. But Dr. Copley has managed to see the wood in spite of the trees.

Specialists will welcome the bibliography of local publications. So many local societies publish bulletins nowadays that it becomes difficult even to keep check of their names. In respect of the very valuable gazetteer of sites and finds, one can really only criticize the author for not giving any reference to where the finds were published. He says this could not be done without extending the gazetteer to an inordinate length. But the usefulness of the lists would have been enhanced tenfold if a hieroglyphic had been added to each reference. The hieroglyphics could have been associated with the bibliography. For example, take the "black beauty" from Reculver : palæolithic tools from this place are mentioned by cross-reference under Herne Bay, but no one interested in palæolithic tools from that site can follow up the reference or discover whether they were chance surface finds or the result of systematic excavation and investigation. Should the book run to a second edition it is to be hoped the author will give serious consideration to this very important matter. But it is not on a note of criticism that one wants to conclude. The work is, of its kind, excellent; a wide area is covered, and a good picture given of mankind's existence in the region over a long period of time. The author is to be congratulated.

M. C. BURKITT 